\title{
Prevalence of Hepatitis-B virus and HIV infections in Pregnant Women Receiving Antenatal Care Services, Kano - Nigeria
}

\author{
Sulaiman Danjuma Dausayi ${ }^{1} \oplus$, Umar Muazu Yunusa ${ }^{2, *} \oplus$, Isa Yunusa ${ }^{3} \oplus$, \\ Zulaiha Gidado Mukhtar ${ }^{4} \odot$, Anas Lawan Sulaiman ${ }^{5}$, Fatima Sunusi Gaya ${ }^{6} \odot$ \\ ${ }^{1}$ Disease Control and Epidemiology, Kano State Primary Health Care Management Board, Kano, Nigeria \\ 2 Division of Biochemistry, Graduate School of Natural and Applied Sciences, Dokuz Eylül University, Izmir, \\ Turkey \\ ${ }^{3}$ Kampala International University, Department of Biochemistry, Kampala, Uganda \\ 4 Department of Science Laboratory Technology, School of Technology, Kano State Polytechnic, Kano, Nigeria \\ ${ }^{5}$ Department of Biochemistry, Kano University of Science and Technology, Wudil, Kano, Nigeria \\ ${ }^{6}$ Bayero University Kano, College of Clinical Sciences, Department of Medicine and Surgery, Kano, Nigeria \\ *Corresponding author: umarmuazuyunusa@gmail.com
}

\begin{abstract}
The dreadful nature of hepatitis-B virus (HBV) and HIV infections and their common mode of transmission during pregnancy have made them become an important global health problem and a leading cause of maternal complications and neonatal deaths in both developed and developing countries. The current study determined the seroprevalence of HBV and HIV amongst pregnant women receiving antenatal care services in Kano state. Structured questionnaires were distributed to 276 (14-49 years) consenting pregnant women across the six selected health facilities to obtain demographic and socio-economic data. Three (3) $\mathrm{ml}$ of venous blood sample were drawn by venipuncture and centrifuged at $3000 \mathrm{rpm}$ for $5 \mathrm{~min}$. The serum was tested for the presence of HIV antibodies using the Abbott Determine HIV 1/2 test kit and HBV antibodies using a rapid diagnostic test kit (DiaSpot Diagnostics, USA). The $\chi^{2}$ test for independence was determined using GraphPad InStat software (version 3.0). Sociodemographic characteristics of the respondents showed $95.7 \%$ of the respondents as being married, $64.5 \%$ lived in a monogamous family, $62.4 \%$ petty traders, $26.8 \%$ unemployed, $57.4 \%$ of them are $21-30$ years of age, $41.3 \%$ have Quranic education, $28.3 \%$ are 1 st gravida while $36.9 \%$ have more than 4 children. Additionally, $1.4 \%$ of HIV and $8 \%$ of HBV cases were confirmed. The chi-squared test for independence $(\chi 2=13.078$, $\mathrm{P}=0.0003$ ) showed a significant relationship between the two variables. HIV and HBV infections existed in the study group. Regular screening, awareness, and health education programs on the mode of their transmission should be directed to pregnant women to prevent vertical transmission.
\end{abstract}

Keywords: Pregnancy, HIV and Hepatitis-B virus infections

\section{Introduction}

Pregnancy is characterized as a period of reproduction during which a woman carries one or more offspring from the implantation of a fertilized zygote in the uterus throughout 
gestation (Mohamed et al., 2016). However, this exciting time is known to triggers endocrine, physiological, anatomical, biochemical, and immunological response; and to have a wellknown effect in the $\mathrm{T}$ helper 1-T helper 2 balance towards a T helper 2 response, which increases the secretion of regulatory $\mathrm{T}$ cells and in turn depressed immune response thereby resulting in the successful infection and proliferation of viral DNA (Borgia et al., 2012; Costantine, 2014). Human immunodeficiency virus (HIV) and hepatitis B virus (HBV) infections pose a public health challenge causing about two billion infections worldwide (Adegbesan-Omilabu et al., 2015; Platt et al., 2016), with an approximate 350 million people remaining chronically infected (Schilsky, 2013). Out of these, about 50\% acquired their infections either perinatally or in early childhood (Lavanchy, 2005). The appalling nature of both viral infections and their common route of transmission through blood and body fluids especially during unprotected heterosexual contact, mother to child transmission, and ability to cause chronic disease state in affected individuals account for their dual burden of comorbidity during pregnancy (Kourtis et al., 2012).

HBV belong to a member of the hepadnaviridae family and envelops a partially doublestranded DNA virus has numerous antigenic components such as hepatitis $B$ envelope antigen ( $\mathrm{HBeAg})$, hepatitis $B$ core antigen $(\mathrm{HBcAg})$ and hepatitis B surface antigen ( $\mathrm{HBsAg}$ ) (Mekonnen et al., 2018). Due to its vertical transmission nature, hepatitis B is associated with maternal complications, and death accompanied by impaired mental and physical health of the child (Ugbebor et al., 2011). This is followed by liver cirrhosis and hepatocellular carcinoma in young adults (Negero et al., 2011). Its high prevalence ( $>8 \%$ of the population) has been reported in Pacific Islands, South-East Asia, China, the Amazon basin, Sub-Saharan Africa and parts of the Middle-East with intermediated prevalence (2-7\%) in Eastern and Southern Europe, Central and South America, South Asia, and Russia. On the other hand, the areas with low endemicity $(<2 \%)$ include Australia, Western Europe, and the United States (Te and Jensen, 2010; World Health Organization, 2013). In Nigeria, different prevalence rate of $\mathrm{HBV}$ in pregnant women was reported in different localities amongst which are $7.3 \%, 8.2 \%$ and $16.3 \%$ documented by Adegbesan-Omilabu et al. (2015), Olokoba et al. (2011) and Adeyemi et al. (2014), respectively.

Since it was first discovered in 1981 in the United States (Gottlieb et al., 1981), AIDS which was caused by HIV has become a global pandemic (Perpetus et al., 2012) with highest number of people (63\%) with the virus living in sub-Saharan Africa (Adeniran et al., 2014). With about 1.9 million people currently living with HIV in Nigeria, the country has a national prevalence rate of $1.4 \%$ (i.e., $1.9 \%$ women, versus $0.9 \%$ men) among adults aged $15-$ 49 years (Federal Ministry of Health, UNAIDS, and National Agency for the Control of AIDS, 2019). Previous estimates had indicated a national HIV prevalence of 2.8\% (about 3.1 million people) (AVERT global information and education on HIV and AIDS, 2018). Potential vertical transmission of this deadly virus (HIV) during the gestation period is a major concern, because of the attendant consequences of morbidity and mortality of these infections (Kourtis et al., 2012). The infection, if it happens, pre-exposes the children to common childhood diseases like measles, diarrhoea, common cold, etc. that can be used as markers of immune decline (Makokha et al., 2003). Thus, the present study aimed to determine the prevalence of HIV and HBV amongst pregnant women attending some antenatal care services in Kano state primary health care management board. 


\section{Materials and Method}

\subsection{Target Population}

The study population included primi and multi-gravid pregnant women (14-49 years) attending antenatal services in six zones in Kano state primary health care management board. A total of 276 consented pregnant women were recruited for the study.

\subsection{Sample Size Determination}

By taking Adeyemi et al. (2014)'s 16.3\% prevalence rate of HBV, the sample size was determined using the formula, $\mathrm{N}=\frac{\mathrm{z}^{\mathrm{z}} \mathrm{p}(1-\mathrm{p})}{\mathrm{d}^{\mathrm{z}}}$ (Bartlett et al., 2001) where

$\mathrm{N}=$ sample size

$\mathrm{d}=$ margin of error $(5 \%)$

$\mathrm{p}=$ prevalence of $16.3 \%$

$\mathrm{z}=$ critical value at $95 \%$ confidence level (1.96)

Substituting the above values in the given formula yields

$\mathrm{N}=\frac{(1.96)^{2} \times 0.163(0.837)}{(0.05)^{2}}=209.6$

Therefore, a minimum sample size of 210 is obtained. Adjusting for attrition, the sample size was rounded up to 276 pregnant women.

\subsection{Sampling Technique}

Six hospitals (one from each zone) were randomly selected using systematic sampling. The number of consenting respondents in each hospital was 46 (totaling 276). Respondents were randomly recruited through systematic sampling for the study on different clinic days.

\subsection{Data Collection}

A structured questionnaire was designed and administered to consented pregnant women. The questionnaire contained some socio-demographic and economic characteristics of the participants. Figure 1 shows respondent filling the questionnaire.

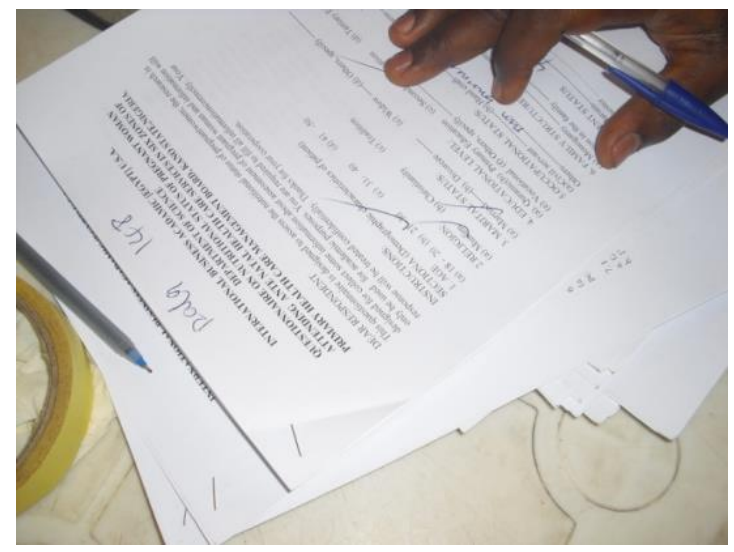

Figure 1. A respondent filling the questionnaire 


\subsection{Informed Consent and Ethical Issues}

Informed consents were obtained from the respondents before sample collection and all data were kept confidential in accordance with world medical association ethical principle for medical research involving human subjects (World Medical Association, 2013). Ethical clearance was sought and obtained from Kano state ministry of health prior to commencement of the study.

\subsection{Assay}

A $3 \mathrm{ml}$ venous blood sample was drawn by venipuncture (Figure 2) from women and collected in a labelled plain universal specimen bottle. Each clotted sample was centrifuged at $3000 \mathrm{rpm}$ for $5 \mathrm{~min}$. The serum was subsequently separated from each blood sample and stored frozen $\left(-20^{\circ} \mathrm{C}\right)$ until further analysis. Each pregnant woman's serum was tested for the presence of HIV antibodies using Abbott Determine HIV 1/2 test kit (Abbot Laboratories, Illinois, USA) and HBV antibodies using rapid diagnostic tests (DiaSpot Diagnostics, USA). The standard operating procedures (SOPs) of each of the manufacturers were strictly followed.

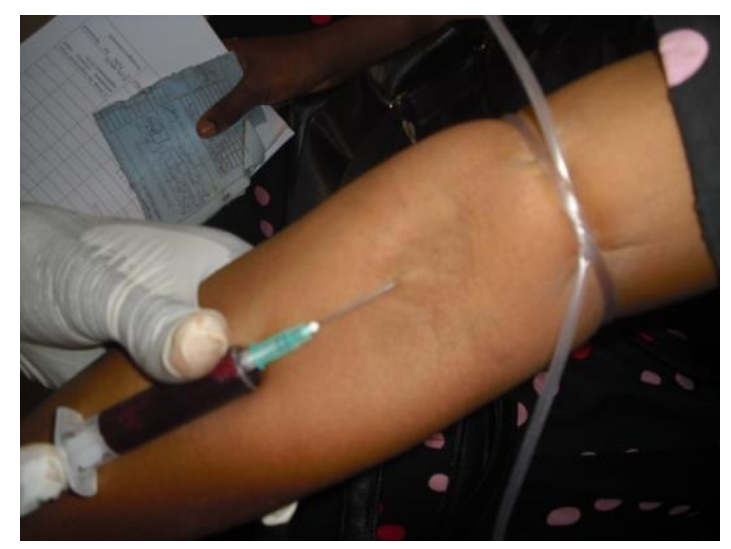

Figure 2. Blood sample being drawn by venipuncture

\subsection{Data Analysis}

The data retrieved were analyzed and depicted in the tables using percentages and proportions to compute the socio-demographic and economic variables. A chi-squared test for independence was used for inferential statistics to determine the possible relationship among the variables of the study.

\section{Results}

The economic and demographic characteristics of the respondents are presented in Table 1. The majority of the respondents have Quranic education $(41.3 \%) ; 2.2 \%$ studied up to the advanced level, $62.4 \%$ are petty traders and $26.8 \%$ are unemployed. Likewise, $57.4 \%$ (representing the majority) of the respondents are in the range of 21 - 30 years of age, minority ( $8 \%$ ) are in between $41-50$ years of age, $95.7 \%$ are married, and $64.5 \%$ are living in a monogamous family, $36.9 \%$ have more than 4 children and $28.3 \%$ are 1 st gravida mothers. 
Table 1. Socio-demographic features of the population under study

\begin{tabular}{|c|c|c|}
\hline Variables & N (276) & Percentage (\%) \\
\hline \multicolumn{3}{|c|}{ Employment type } \\
\hline Civil servant & 10 & 3.6 \\
\hline Handcraft & 18 & 6.5 \\
\hline Trading & 172 & 62.4 \\
\hline Unemployed & 74 & 26.8 \\
\hline Others & 2 & 0.7 \\
\hline \multicolumn{3}{|l|}{ Family type } \\
\hline Monogamy & 178 & 64.5 \\
\hline Polygamy & 98 & 36.5 \\
\hline \multicolumn{3}{|l|}{ Marital status } \\
\hline Married & 264 & 95.7 \\
\hline Divorced & 8 & 2.9 \\
\hline Widow & 4 & 1.4 \\
\hline \multicolumn{3}{|l|}{ Religion } \\
\hline Islam & 274 & 99.3 \\
\hline Christianity & 02 & 0.7 \\
\hline \multicolumn{3}{|c|}{ Educational level } \\
\hline Quranic & 114 & 41.3 \\
\hline Primary & 48 & 17.4 \\
\hline Secondary & 106 & 38.4 \\
\hline Tertiary & 6 & 2.2 \\
\hline Vocational & 2 & 0.7 \\
\hline \multicolumn{3}{|l|}{ Age (years) } \\
\hline $11-20$ & 62 & 22.5 \\
\hline $21-30$ & 142 & 57.4 \\
\hline $31-40$ & 50 & 18.1 \\
\hline $41-50$ & 22 & 8.0 \\
\hline \multicolumn{3}{|l|}{ Gravidarum } \\
\hline 1 & 78 & 28.3 \\
\hline 2 & 44 & 15.9 \\
\hline 3 & 22 & 8.0 \\
\hline 4 & 30 & 10.9 \\
\hline $4+$ & 102 & 36.9 \\
\hline
\end{tabular}

Table 2 presents the infectious status of pregnant women. Out of 276 consented pregnant women 4 are HIV seropositive giving a prevalence of $1.4 \%$. Likewise, 22 out of 276 study participants $(8 \%)$ are also seropositive for HBV test. All in all, the number of respondents with HBV infections are higher than that of HIV. The chi-squared test for independence (13.078) showed the two variables to be significantly associated with each other $(\mathrm{P}=0.0003)$ and each infection had a significant relationship with the other group. 
Table 2. Infectious status of a pregnant woman

\begin{tabular}{lllll}
\hline Parameter & \multicolumn{2}{l}{ Reactive } & \multicolumn{2}{l}{ Non-reactive } \\
\hline & $\mathrm{N}(276)$ & Percentage $(\%)$ & $\mathrm{N}(276)$ & Percentage $(\%)$ \\
\cline { 2 - 5 } HIV & 4 & 1.4 & 272 & 98.6 \\
HBV & 22 & 8 & 254 & 92 \\
\hline
\end{tabular}

Chi-square: 13.078; The $\mathrm{P}$ value is 0.0003

The row and column variables are significantly associated.

\section{Discussion}

Viral diseases such as HIV and HBV are life-threatening diseases that have become an important public health issue in both developed and developing countries. The problem tends to be more profound in sub-Saharan Africa including Nigeria. During pregnancy, HIV and HBV screening is important to initiate early antiretroviral therapy (ART) that improves maternal health and prevent the risk of vertical transmission (mother to child) of retroviral diseases (Günthard et al., 2016). Taking this into consideration, the present study investigated the prevalence of HIV and HBV amongst pregnant women in the study area. Results presented from the present study in Table 2 showed the prevalence of HBV infection as $8 \%$. This value is similar to 7.9\% (Jatau et al., 2009; Yakasai et al., 2012), 8.2\% (Olokoba et al., 2011), 8.3\% (Luka et al., 2008; Anaedobe et al., 2015) but quite differ with 2.2\% (Mbamara and Obiechina, 2010), 4.89\% (Caroline et al., 2016), 7.3\% (Adegbesan-Omilabu et al., 2015), 12\% (Mbaawuaga et al., 2014; Musa et al., 2015), 16.3\% (Adeyemi et al., 2014) prevalence figures documented in various studies and in various locations in Nigeria. This level of endemicity is worrisome considering the consequences both for the mother's health and that of her baby. Without treatment, HBV infection can progress chronically and may be clinically asymptomatic, or may progress to cause liver cancer or liver damage that leads to liver failure (Molla et al., 2015). It can also progress to attack and damage ovarian follicle or placental capillary endothelium (Yu et al., 2013).

The 1.4\% HIV prevalence obtained in the current study is the same as the 2019 national HIV prevalence rate of $1.4 \%$ reported by the federal ministry of health (FMoH), UNAIDS and national agency for the control of AIDS (NACA) among women of reproductive ages (15-49 years) living in Nigeria (Federal Ministry of Health et al., 2019). However, this value is lower than $2.8 \%$ of previous national estimates (AVERT global information and education on HIV and AIDS, 2018); and 3.0\% (Okerentugba et al., 2015), 3.2\% (Isichei et al., 2015), 4.9\% (Ibrahim et al., 2013), 5.9\% (Caroline et al., 2016); but higher than 0.95\% (Ajoge et al., 2008) previously reported in various localities in Nigeria. The low HIV prevalence observed in the present study could be explained by the effort of various government and non-governmental agencies programs in the country in raising awareness about the importance of HIV screening and its prevention. Pregnant women infected with HIV have an increased risk of anemia, hypertensive disease, hemorrhage due to thrombocytopenia (Caroline et al., 2016), eight times higher mortality rate and three times the risk of puerperal sepsis in comparison with non-infected negative women (Calvert and Ronsmans, 2013; Zaba et al., 2013). These consequences tend to progress to their offspring, immediate family, health workers, social and economic structure (Egesie and Mbooh, 2008). In general, this prospective cohort study shows HBV infections as having a higher prevalence than HIV. Hepatitis B and human immunodeficiency viruses tests during gestation benefit the women in the reinforcement of 
safe sex practices, provision of opportunity for counselling on infant feeding options, and enabling a woman to make informed choices about future pregnancies.

\section{Conclusion}

The findings of the present study conclude that viral infections of hepatitis and human immunodeficiency does exist amongst the study group with HBV having a higher endemicity of $8 \%$. To decrease the prevalence of these viral infections, we recommend that all pregnant women should be screened for HIV and HBV, and health education programs on the mode of their transmission to prevent mother-to-child transmission should be instituted in all antenatal care clinics to raise the awareness to mothers.

\section{Author Statement}

The authors confirm contribution to the paper as follows: study conception and design: Sulaiman Danjuma Dausayi, Isa Yunusa; data collection: Sulaiman Danjuma Dausayi, Fatima Sunusi Gaya, Anas Lawan Sulaiman; analysis and interpretation of results: Umar Muazu Yunusa, Isa Yunusa, Zulaiha Gidado Mukhtar; draft manuscript preparation: Umar Muazu Yunusa, Zulaiha Gidado Mukhtar. All authors reviewed the results and approved the final version of the manuscript.

\section{Conflict of Interest}

The authors declare no conflict of interest.

\section{References}

Adegbesan-Omilabu, M. A., Okunade, K. S., Gbadegesin, A., Olowoselu, O. F., Oluwole, A. A., \& Omilabu, S. A. (2015). Seroprevalence of hepatitis B virus infection among pregnant women at the antenatal booking clinic of a Tertiary Hospital in Lagos Nigeria. Nigerian Journal of Clinical Practice, 18(6), 819-823.

Adeniran, A. S., Raji, S. T., Saidu, R., \& Omokanye, L. O. (2014). Partner disclosure and human immunodeficiency virus serology status among antenatal clinic attendees with human immunodeficiency virus infection in Ilorin. Journal of Medical Investigations and Practice, 9(3) 112-115.

Adeyemi, A. B., Enabor, O. O., Ugwu, I. A., Abraham, O. A., Bello, F. A., \& Olayemi, O. (2014). Prevalence of antenatal hepatitis B infection in tertiary and non-tertiary health facilities in Ibadan, Nigeria. Nigerian journal of medicine: journal of the National Association of Resident Doctors of Nigeria, 23(3), 248-253.

Ajoge, H. O., Ahmad, A. A., Olonitola, O. S., Abdulsalam, A., Onujabe, M. I., Muktar, H. M., \& Shittu, S. O. (2008). The prevalence of human immunodeficiency virus infection among pregnant women in rural settlements of Ebira-land. International Journal of Biological and Chemical Sciences, 2(1).

Anaedobe, C. G., Fowotade, A., Omoruyi, C. E., \& Bakare, R. A. (2015). Prevalence, sociodemographic features and risk factors of Hepatitis B virus infection among pregnant women in Southwestern Nigeria. The Pan African Medical Journal, 20(406), 1-11.

AVERT. Global information and education on HIV and AIDS. HIV and Aids in Nigeria. 2018. Available: https://www.avert.org/professionals/hiv-around-world/sub-saharanafrica/nigeria\#ffootnote2_cisibwc. [Accessed: July 8, 2019]. 
Bartlett, J. E., Kotrlik, J. W., Higgins, C. C. (2001). Organizational research: Determining appropriate sample size in survey research. Information Technology, Learning, and Performance Journal, 19(1), 43-50.

Borgia, G., Carleo, M. A., Gaeta, G. B., \& Gentile, I. (2012). Hepatitis B in pregnancy. World journal of gastroenterology: WJG, 18(34), 4677.

Calvert, C., \& Ronsmans, C. (2013). HIV and the risk of direct obstetric complications: a systematic review and meta-analysis. PloS one, 8(10), e74848.

Caroline, I., Hannah, O., \& Adaunwo, O. D. (2016). A Retrospective Study of the Seroprevalence of Antibodies to HbsAg, HIV-1/2 And Syphilis Amongst Pregnant Women At Booking In A Tertiary Hospital In Port Harcourt, Southern Nigeria. IOSR Journal of Dental and Medical Sciences, 15(6), 86-92.

Costantine, M. (2014). Physiologic and pharmacokinetic changes in pregnancy. Frontiers in Pharmacology, 5, 65.

Egesie, U., \& Mbooh, T. (2008). Seroprevalence of human immunodeficiency virus (hiv) infection in pregnant women in amassoma, nigeria. African Journal of Biomedical Research, 11(1), 111-113.

Federal Ministry of Health, UNAIDS, and National Agency for the Control of AIDS (NACA). New survey results indicate that Nigeria has an HIV prevalence of 1.4\% 2030 - End. AIDS epidemic. 2019. Available: https://www.unaids.org/en/resources/ presscentre/pressreleaseandstatementarchive/2019/march/20190314_nigeria.

[Accessed: July 8, 2019].

Gottlieb, M. S., Schroff, R., Schanker, H. M., Weisman, J. D., Fan, P. T., Wolf, R. A., \& Saxon, A. (1981). Pneumocystis carinii pneumonia and mucosal candidiasis in previously healthy homosexual men: evidence of a new acquired cellular immunodeficiency. New England Journal of Medicine, 305(24), 1425-1431.

Günthard, H. F., Saag, M. S., Benson, C. A., Del Rio, C., Eron, J. J., Gallant, J. E., et al. (2016). Antiretroviral drugs for treatment and prevention of HIV infection in adults: 2016 recommendations of the International Antiviral Society-USA panel. Jama, 316(2), 191210.

Ibrahim, I. A., Owoeye, G. I., \& Obilahi, A. (2013). The burden of HIV infection among women attending antenatal clinic in a semi-urban Nigerian town. West Indian Medical Journal, 62(4), 323-328.

Isichei, C., Brown, P., Isichei, M., Njab, J., Oyebode, T., \& Okonkwo, P. (2015). Hiv Prevalence and Associated Risk Factors Among Rural Pregnant Women in North Central Nigeria. Am. J. Heal. Res., 3(1), 18-23.

Jatau, E. D., \& Yabaya, A. (2009). Sero prevalance of Hepatisis B Virus in pregnant women attending a clinic in Zaria, Nigeria. Science World Journal, 4(2), 7-9.

Bartlett, J. E., Kotrlik, J. W., Higgins, C. C. (2001). Organizational research: Determining appropriate sample size in survey research. Information Technology, Learning, and Performance Journal, 19(1), 43-50.

Kourtis, A. P., Bulterys, M., Hu, D. J., \& Jamieson, D. J. (2012). HIV-HBV coinfection - A global challenge. New England Journal of Medicine, 366(19), 1749-1752.

Lavanchy, D. (2005). Worldwide epidemiology of HBV infection, disease burden, and vaccine prevention. Journal of Clinical Virology, 34, S1-S3. 
Luka, S. A., Ibrahim, M. B., \& Iliya, S. N. (2008). Sero-prevalence of hepatitis B surface antigen among pregnant women attending Ahmadu Bello University Teaching Hospital, Zaria, Nigeria. Nigerian Journal of Parasitology, 29(1), 38-41.

Makokha, E. P., Ogolla, M., Orago, A. S. S., Koech, D. K., Mpoke, S., Esamai, F., ... \& Tukei, P. M. (2003). CD4T Lymphocyte subsets and disease manifestation in children with and without HIV born to HIV-1 infected mothers. East African Medical Journal, 80(2), 95100.

Mbaawuaga, E. M., Iroegbu, C. U., Ike, A. C., \& Jombo, G. T. A. (2014). Studies on prevalence, co-infection and associated risk factors of hepatitis B virus (HBV) and Human immunodeficiency virus (HIV) in Benue State, Nigeria. Science Journal of Public Health, 2(6), 569-576.

Mbamara, S. U., \& Obiechina, N. J. A. (2010). Seroprevalence of hepatitis B surface antigen among antenatal clinic attendees in a private specialist hospital in Onitsha, Southeast Nigeria. Nigerian Medical Journal, 51(4), 152.

Mekonnen, R., Admasu, D., \& Belete, M. (2018). Sero-Prevalence of Hepatitis B Virus and associated factors among pregnant mothers attending antenatal care in Public Health Facilities, Dire Dawa. Journal of Medical Microbiology E Diagnosis, 7(3), 1-8.

Mohamed, A. O., Hamza, K. M., \& Babker, A. M. (2016). Physiological changes in some hematological and coagulation profile among Sudanese healthy pregnant women. International Journal of Medical Science and Public Health, 5(3), 525-528.

Molla, S., Munshea, A., \& Nibret, E. (2015). Seroprevalence of hepatitis B surface antigen and anti $\mathrm{HCV}$ antibody and its associated risk factors among pregnant women attending maternity ward of Felege Hiwot Referral Hospital, northwest Ethiopia: a crosssectional study. Virology Journal, 12(1), 1-9.

Musa, B. M., Bussell, S., Borodo, M. M., Samaila, A. A., \& Femi, O. L. (2015). Prevalence of hepatitis B virus infection in Nigeria, 2000-2013: a systematic review and metaanalysis. Nigerian Journal of Clinical Practice, 18(2), 163-172.

Negero, A., Sisay, Z., \& Medhin, G. (2011). Prevalence of Hepatitis B surface antigen (HBsAg) among visitors of Shashemene General Hospital voluntary counseling and testing center. BMC Research Notes, 4(1), 1-5.

Okerentugba, P. O., Uchendu, S. C., \& Okonko, I. O. (2015). Prevalence of HIV among pregnant women in Rumubiakani, Port Harcourt, Nigeria. Public Health Research, 5(2), 58-65.

Olokoba, A. B., Salawu, F. K., Damburam, A., Olokoba, L. B., Midala, J. K., Badung, H. L., \& Olatinwo, A. W. O. (2011). Hepatitis B virus infection amongst pregnant women in north-eastern-a call for action. Nigerian Journal of Clinical Practice, 14(1), 10-13.

Perpetus, C. I., Fidelis, A. O., Joseph, A., \& Paul, O. E. (2012). Human immunodeficiency virus (HIV) seroprevalence and pregnancy outcome among obstetric population in Abakaliki, Southeast Nigeria. Journal of Public Health and Epidemiology, 4(10), 290-293.

Platt, L., Easterbrook, P., Gower, E., McDonald, B., Sabin, K., McGowan, C., ... \& Vickerman, P. (2016). Prevalence and burden of HCV co-infection in people living with HIV: a global systematic review and meta-analysis. The Lancet Infectious Diseases, 16(7), 797808.

Schilsky, M. L. (2013, April). Hepatitis B “360”. In Transplantation Proceedings (Vol. 45, No. 3, 982-985). Elsevier. 
Te, H. S., \& Jensen, D. M. (2010). Epidemiology of hepatitis B and C viruses: a global overview. Clinics in Liver Disease, 14(1), 1-21.

Ugbebor, O., Aigbirior, M., Osazuwa, F., Enabudoso, E., \& Zabayo, O. (2011). The prevalence of hepatitis B and C viral infections among pregnant women. North American Journal of Medical Sciences, 3(5), 238-241.

World Health Organization. (2013). Global policy report on the prevention and control of viral hepatitis in WHO Member States. 1-220.

World Medical Association. (2013). Declaration of Helsinki: ethical principles for medical research involving human subjects. JAMA, 310(20): 2191-2194.

Yakasai, I. A., Ayyuba, R. U., Abubakar, I. S., \& Ibrahim, S. A. (2012). Sero-prevalence of hepatitis B virus infection and its risk factors among pregnant women attending antenatal clinic at Aminu Kano Teaching Hospital, Kano, Nigeria. Journal of Basic and Clinical Reproductive Sciences, 1(1-2), 49-55.

Yu, M., Jiang, Q., Gu, X., Ju, L., Ji, Y., Wu, K., \& Jiang, H. (2013). Correlation between vertical transmission of hepatitis $\mathrm{B}$ virus and the expression of HBsAg in ovarian follicles and placenta. PloS one, 8(1), e54246.

Zaba, B., Calvert, C., Marston, M., Isingo, R., Nakiyingi-Miiro, J., Lutalo, T., ... \& Ronsmans, C. (2013). Effect of HIV infection on pregnancy-related mortality in sub-Saharan Africa: secondary analyses of pooled community-based data from the network for Analysing Longitudinal Population-based HIV/AIDS data on Africa (ALPHA). The Lancet, 381(9879), 1763-1771. 